(川口化學工業株式合社)（昭 和 17 年 7 月 14 日受理）

\title{
(170～17I） 生ゴムの可塑化に關する研究（第9１0報）
}

\author{
君島卓 三・而山俊一
}

\section{（第 9 報） 加硫促進劑の可塑性に就て}

加硫促進用の可塑性火就ては Stanly Kroll (Ind. Eng. Chem., 1924，16，922）の研究がある。彼は生ゴム，硫黃，亞鉛華等所

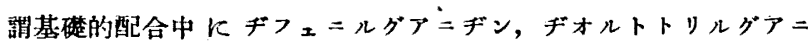
ギン,トリフェニルグアニヂン，アセトアルデヒドアンモニア，メ チレンアニリン，テトラメチルチューラムヂサルファイド等を混合 し其可朔化の狀態とスコーチングの關保に就て觀察した。更KLeblanc 及び Klager (Z. Elektro. Chem, 27, 355) 及び島田慶一 氏（護謨, 昭和 7,513 ) は加硫促進劑の或種のものはゴム溶液の粘 度を低下する性質のあるてとを報告した。

湿儿著者等はメルカプタン類の生ゴムの可塑化現象に就て研究

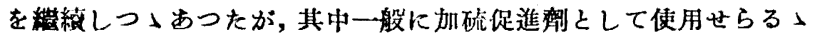
チオカーバニライド，メルカプトベンゾチアゾールの如き化合物が 著明なる可塑性を有することを認めをるを以て宽用的見地より一 般加硫促進劑の可塑性を探查するも徒勞ならざると信じ浜驗を行 つたあのである。著者等の研究目標は前研究者等のそれ之可成り其 趣を異にし，ゴム工業儿於て生ゴム處理中素煉時間の短縮と加硫ゴ

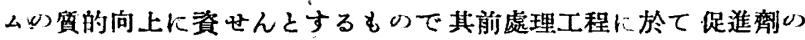
使用を合理化せんとするるのである。

\section{1. 試料 の調 製}

試料に供したる促進劑は現今專ら賽用に供せられつ」ある重要 促進劑で特に單一化合物よりなるものを選んだ。其儘試料とする 考へであつたが各商品は製作所により著しく品位を異にし，其儘

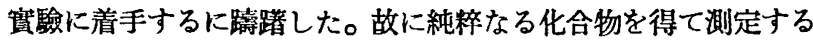
ことが標準的ならんと信じ，之等市販品を精製し，精製不可能な るものは出登原料より精製して合成した。又特徽ある促進劑は其 價使用することにした。其精製法と試料の品位を次表に示す。

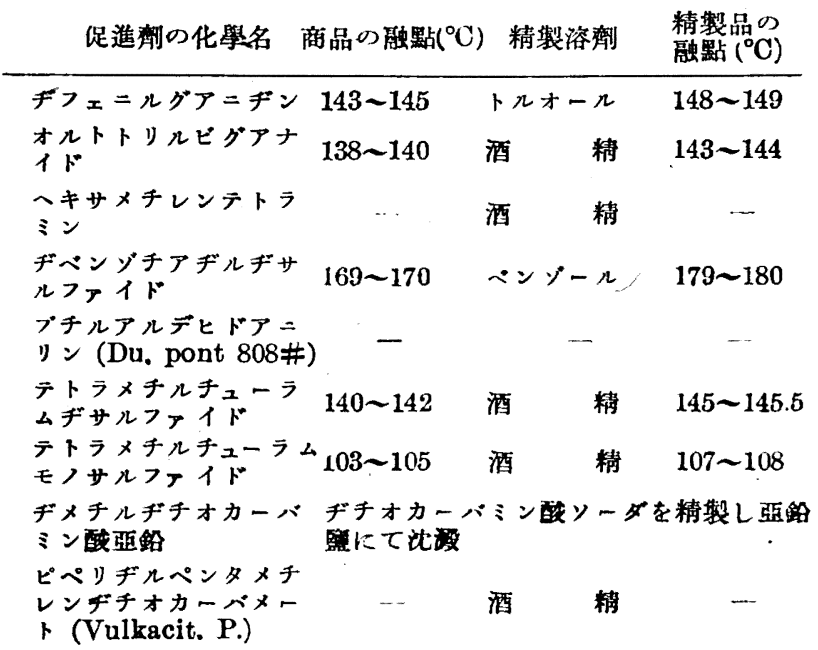

精諘したる試料は乾燥の後瑪瑙乳鉢にて良く擂り細末として使 用した。

\section{2. 宽 羷 結 果}

本研究に於ける可塑性の测定は筫用的なる䉆精密を要せざるに よりゴム・ベンゾール溶液の 粘度低下測定と $100^{\circ} \mathrm{C}$ に於ける可 塑計测定とを省略して $70^{\circ} \mathrm{C}$ の恒溫槽に放置の後测定する方法に 揲つた。試料の添加量は從來の研究に從ひ $0.5 \%$ を混合し其他詳 細な處理法に就ては本研究第 2 報を照されたい。

促進劑中メルカプトベンゾチアゾールの䆩驗結果は既に本研究 の第 7 報に記載したるを以て其結果を其鰛探用した。

第 1 表 ヂフェニルグアニデン

\begin{tabular}{cccc} 
䊒過時間(時) & 軟化度 & 保持度 & 可塑度 \\
\hline 0 & 0.2458 & 0.6356 & 0.1561 \\
1 & 0.2660 & 0.6365 & 0.1695 \\
3 & 0.2515 & 0.6287 & 0.1581 \\
5 & 0.2611 & 0.6272 & .0 .1668 \\
7 & 0.2600 & 0.6255 & 0.1625 \\
12 & 0.2525 & 0.6215 & 0.1570 \\
24 & 0.2356 & 0.6099 & 0.1459 \\
36 & 0.2491 & 0.6302 & 0.1569 \\
48 & 0.2249 & 0.5994 & 0.1346
\end{tabular}

第 2 表 オルトトリルビグアナイド

\begin{tabular}{ccccc} 
縔過時間(時) & 僌化度 & & 保持庭 & 可塑度 \\
\cline { 1 - 2 } \cline { 5 - 5 } $\mathbf{0}$ & 0.2436 & & 0.6084 & 0.1485 \\
1 & 0.2321 & & 0.5820 & 0.1352 \\
3 & 0.2513 & & 0.5876 & 0.1476 \\
5 & 0.2379 & & 0.5906 & 0.1405 \\
7 & 0.2413 & & 0.5870 & 0.1417 \\
12 & 0.2330 & & 0.5900 & 0.1375 \\
24 & 0.2450 & & 0.5870 & 0.1436 \\
36 & 0.2378 & & 0.5776 & 0.1350 \\
48 & 0.2370 & & 0.5734 & 0.1357
\end{tabular}

ヂフェニルグアニヂン,オルトトリルビグナナイドは共に强孟 基性の化合物で前者は測定の初期に稍々軟化し僅の可塑性が認め られる。然るに數時間にして減退を示し此結果より見て可塑性と 稱するよりも寧ろ軟化性と稱したい。後者は殆ど變化なく完全に 軟化及び可塑性を與へない。

第 3 圆 ヘキサメチレンテトラミン

\begin{tabular}{cccc} 
結過時間(時) & 軟化度 & 保持度 & 可塑度 \\
\hline 0 & 0.2510 & 0.6372 & 0.1596 \\
1 & 0.2876 & 0.6400 & 0.1830 \\
3 & 0.2877 & 0.6408 & 0.1842 \\
5 & 0.2627 & 0.6383 & 0.1673 \\
7 & 0.2579 & 0.6280 & 0.1618 \\
12 & 0.2579 & 0.6270 & 0.1616 \\
24 & 0.2475 & 0.6163 & 0.1526 \\
36 & 0.2454 & 0.6136 & 0.1505 \\
.48 & 0.2417 & 0.6034 & 0.1456
\end{tabular}


第 4 表 ブチルアルデヒドアニリン

\begin{tabular}{cccc} 
経過時間(時) & 軟化度 & 保持度 & 可塑度 \\
\hline 0 & 0.2548 & 0.6318 & 0.1607 \\
1 & 0.2653 & 0.6369 & 0.1682 \\
3 & 0.2594 & 0.6255 & 0.1621 \\
5 & 0.2787 & 0.6311 & 0.1756 \\
7 & 0.2695 & 0.6158 & 0.1596 \\
12 & 0.2559 & 0.6009 & 0.1536 \\
24 & 0.2552 & 0.6103 & 0.1559 \\
36 & 0.2445 & 0.6001 & 0.1466 \\
48 & 0.2295 & 0.5889 & 0.1356
\end{tabular}

兩者共大體類似の結果を得たが僅に測定の初期に前者が優る樣 である。概して整基性促進劑より優れるが然し㛙れも時間と共に 漸減する。可塑性に就てはアルデヒドァミン系促進劑は僌化性大 であるから其性質を考慮する必要がある。

第 5 表 ヂベンゾチアヂルデサルファイド

\begin{tabular}{cccc} 
經過時閏(時) & 軟化度 & 保持度 & 可塑度 \\
\hline 0 & 0.2374 & 0.5739 & 0.1364 \\
1 & 0.2415 & 0.6330 & 0.1528 \\
3 & 0.2311 & 0.6156 & 0.1419 \\
5 & 0.2423 & 0.6435 & 0.1560 \\
7 & 0.2292 & 0.5994 & 0.1375 \\
12 & 0.2273 & 0.6103 & 0.1370 \\
24 & 0.2230 & 0.6097 & 0.1359 \\
36 & 0.2289 & 0.6089 & 0.1393 \\
48 & 0.2466 & 0.5888 & 0.1476
\end{tabular}

第 6 表 テトラメチルチ之ーラムヂサルファイド

\begin{tabular}{cccc} 
經過時間(時) & 軟化度 & 保持度 & 可塑度 \\
\hline $\mathbf{0}$ & 0.2316 & 0.6310 & 0.1461 \\
1 & 0.2345 & 0.6420 & 01501 \\
3 & 0.2342 & 0.6248 & 0.1464 \\
5 & 0.2271 & 0.6178 & 0.1404 \\
7 & 0.2423 & 0.6315 & 0.1536 \\
12 & 0.2116 & 0.5995 & 0.1269 \\
24 & 0.2219 & 0.6053 & 0.1341 \\
36 & 0.2200 & 05895 & 0.1296 \\
48 & 0.2143 & 0.5811 & 0.1245
\end{tabular}

第 7 表 テトラメチルチューラムモノサルファイド

\begin{tabular}{cccc} 
經過時間(時) & 軟化度 & 保持度 & 可塑度 \\
\hline 0 & 0.2467 & 0.5847 & 0.1391 \\
$\mathbf{3}$ & 0.2827 & 0.6307 & 0.1782 \\
3 & 0.2804 & 0.6330 & 0.1774 \\
5 & 0.2854 & 0.6210 & 0.1771 \\
7 & 02835 & 0.6292 & 0.1780 \\
12 & 0.2862 & 0.6280 & 0.1796 \\
24 & 0.2601 & 0.6026 & 0.1574 \\
36 & 0.2581 & 0.6046 & 0.1562 \\
48 & 0.2649 & 0.6072 & 0.1605
\end{tabular}

第 8 表 ヂメチルヂチイカーバミン酸亞鉛

\begin{tabular}{cccc} 
䌡過時間(時) & 軟化度 & 保持度 & 可塑度 \\
\hline 0 & 0.1443 & 0.4528 & 0.0641 \\
1 & 0.1631 & 0.5085 & 0.0828 \\
3 & 0.1560 & 0.5080 & 0.0781 \\
5 & 0.1580 & $0.5: 37$ & 0.0822 \\
7 & 0.1656 & 05180 & 0.0884 \\
12 & 0.1605 & 0.5280 & 0.0836 \\
24 & 0.1432 & 0.4779 & 0.0680 \\
36 & 0.1567 & 0.5112 & 0.0797 \\
48 & 0.1431 & 0.4798 & 0.0687
\end{tabular}

第 9 表 ピペリヂルペンタメチレンヂチオカーパメート

\begin{tabular}{cccc} 
釈過時間(時) & 軟化度 & 保持度 & 可塑度 \\
\hline 0 & 0.1951 & 0.5171 & 0.0948 \\
1 & 0.1952 & 0.5751 & 0.1111 \\
3 & 0.1968 & 05431 & 0.1016 \\
5 & 0.1875 & 0.5364 & 0.1012 \\
7 & 0.1907 & 0.5666 & 0.1073 \\
12 & 0.1830 & 0.5562 & 01027 \\
24 & 0.1693 & 0.6061 & 0.0873 \\
36 & 0.1724 & 0.5774 & 0.0997 \\
48 & 0.1829 & 0.5423 & 0.1000
\end{tabular}

ヂベンゾチアヂルヂサルファイドは測定初期 2, 3 時開に於て は可塑性を現す如く見えたが。間もなく泍減的となつた。テトラ メチルチューラムヂサルフっイドに對しモノサルファイドが寧ろ 好結果を與へたるは注目に值する。ヂチオカーバミン酸然類殊に 亞鉛辟は可塑性殆どなく促進劑基ものが軟化性をも有せざること が判る。

\section{3. 結 果 の 考察}

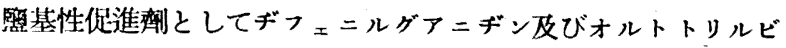
グアナイドの 2 種を選んだが前者に就ては Stanly Kroll に依 れば基礎配合に於て僅の可塑性を認め，其他の充填劑配合の場合 にも其影響を述べた。著者等の赛驗は素娻時に於ける促進劑配合 なるを以て其趣を巽にするが僅に 可塑倾向を示した點は.Stanly K roll の記述と一致する，然るにビグァナイドは全く可塑性を示 さず，兩促進劑共加硫促進劑として使用して得たる加硫ゴムは硬 度を㴰加し殊に後者の場合の方が著しい點を一般に經驗するとこ ろで本賽驗の結果を看て此場合に於ても其影響が幾分に加味せら れるものと思考せられる。

夯にアルデヒドアミン系促進劑としてへキサメチレンテトラミ ン及びブチルアルデヒドァニリンの 2 種に就き實驗を行つたがメ ルカプトベンゾチアゾールに次で可塑性を示した。此種の促進劑 は元來ゴムを軟化する特性があり，好んで筫用に供せらる〉が窂 ろ可塑性として考へるより为軟化性として認むる方が穻當なりと 考へられる。

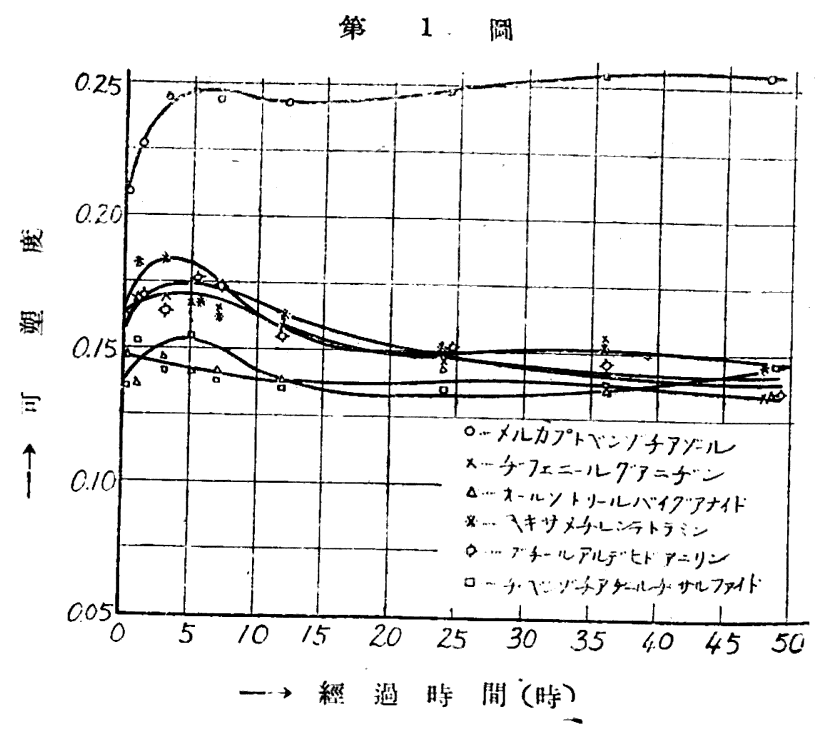

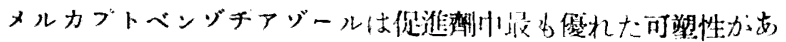

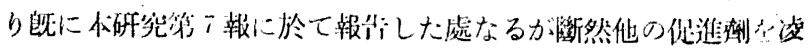


駕し之に追從を許さない。然るに其酸化物たるヂごシデチアヂル ヂサルブ、イドは殆ど可塑性なく其結果は加硫促進性とは反對の 性質を現すもので，郎ち加硫促進劑として働く場合には加硫溫浬 に於て副生した硫化水素の還元作用によりメルカプトベンゾチア ゾールを生じ促進效果を發現すると稱せらるつが，可塑性測定特 に於ては硫化水素の共存なく測定榅度の如き低温にてはメルカプ タンにまでの還元は起らない,從て可塑效果を與へないものと思 考せられる。

第 2 周

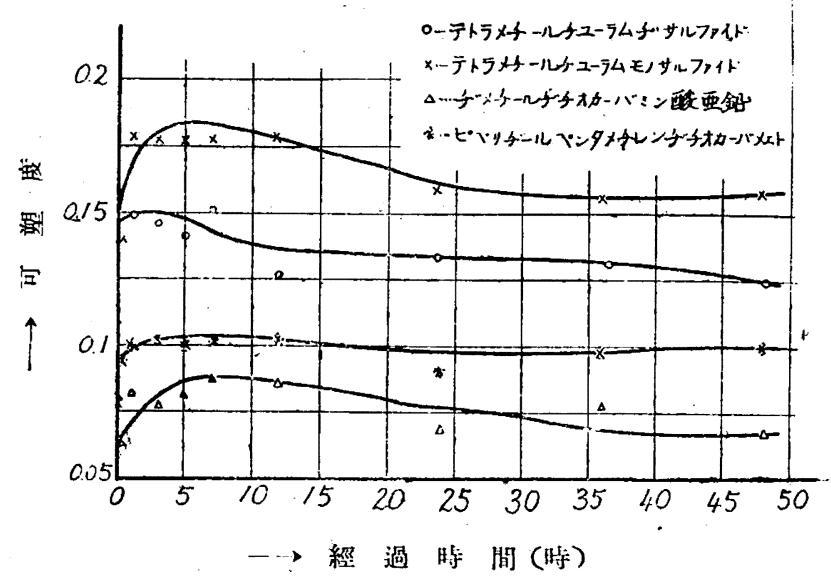

テトラメチルチューラムヂサルフ フイドは生ゴムを軟化し又近 年合成ゴムの慜造捏頭するに至り，之が僌化劑として使用せらる と稱せらるっにより生ゴム可塑性に對しても多少の期待を晒けた のであるが, 其賽驗結果はアルデヒドアミン類の夫にも及ばず寧 ろ其モノサルファイドの方が滛に優る結果を示したる點は極めて 興味ある事實である。ヂチオカーパミ酸其もヤはメルカプタン を有するが遊離酸として存在がなく其酸化物たるチューラムが可 塑性を有しない事實はメルカプトベンゾチアデールと其デサルフ ェイドの關係と極めて類似し，其可塑性の缺如せる默の說明も同 樣と思はる。

ヂチオカーバミン酸盤類でピ ゙リヂルペンタメチレンヂチオカ ーバメートはヂチオ酸のアミン暨抑制によることは明嘹で，加ふ るにヂィチルヂチオカーバミン酸亞鉛は强力なる亞鉆結合を加味 したることにより可塑性缺如の理闫を說明することが出來ると思 はれる。

要するに可塑能力ありと認められた促進劑は結局メルカブトべ ンゾチアゾールのみに止まるが，現れたる結果より順に列記する そアルデヒドアミン類, チューラムモ゙サルファイド, ヂサルファ イド, デフェニルグアニヂンの 5 種を擧げることが出來て之等の 結果より本研究に探用洩九の他の多くの促進剂に就ても化合物の 構跕なり性質より其大體の㑯向を推定することが可能 と思はれ る。

\section{4. 總括}

1. 加硫促進劑の可塑傾向を試簽し照基性促進劑中 D.P.G. は 微かに可塑性を諗め得たがビグアナイドは全然認めなかつた。 。

2.メルカプトベンゾチアゾールは可成り隻秀な叮塑性を現し たが之に反し其酸化物たるヂサルフっイドは可塑性を消失する。

3. チューラム系优進楋中テトラメチルチューラムヂサルフ
イドは僅か乍ら可塑性を認めたが，却てモノサルフ、イドのオ゙が 遥に强く働いた。

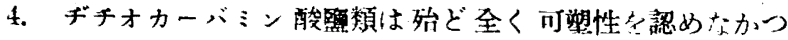
た。

\section{（第 10 報） 老化防止变の可塑性と促進 乵の併用による可塑化傾向に就て}




んとする。老化防止劑はアルドール




に冬種の促進劑及び老化防止劑走併用した。

\section{1. 試料 の 調 製}

アルドールメ゙ーフチルアミンは普通溶劑の如きを使用して精 製不可能なる物質で, 純粹なる結晶を得ること能はず, 樹脂狀に して溶劑處理等によつても重合度を進行する。普通市販品として は重合度低き $\mathrm{A}$ 級と高い $\mathrm{C}$ 級とがあるが本試閤には $\mathrm{C}$ 級を探 用した。試料は川口化學工業株式會社製アンテーヂ C (融點 140〜 $143^{\circ}$ C) を使用した。

フェニルß-ナフチルアミンはエーヂライトバウダーを酒精を以 て再結晶して融點 $107 \sim 108^{\circ} \mathrm{C}$ のものとなした。促進齋は前報告 に記載したものを使用した。

\section{2. 霓 驗 結 果}

可望性測定は前報告と全く同樣である。

第 1 表 アルドールメーナフチルアミン

\begin{tabular}{cccc} 
經過時間(時) & 軟化度 & 保持柪 & 问塑度 \\
\hline 0 & 0.2250 & 0.6013 & 0.1353 \\
1 & 0.2508 & 0.6326 & 0.1585 \\
$\dot{3}$ & 0.2504 & 0.6276 & 0.1570 \\
5 & 0.2575 & 0.6370 & 0.1615 \\
7 & 0.2544 & 0.6250 & 0.1578 \\
12 & 0.2466 & 0.6244 & 0.1540 \\
24 & 0.2421 & 0.6181 & 0.1496 \\
36 & 0.2463 & 0.6150 & 0.1514 \\
48 & 0.2422 & 0.6075 & 0.1465
\end{tabular}

第 2 表 フェニル

\begin{tabular}{cccc} 
經過時間(時) & 軟化度 & 保捇度 & 可塑庭 \\
\hline 0 & 0.2387 & 0.6021 & 0.1483 \\
1 & 0.2636 & 0.6360 & 0.1675 \\
3 & 0.2636 & 0.6297 & 0.1658 \\
5 & 0.2613 & 0.6411 & 0.1675 \\
7 & -0.2661 & 0.6270 & 0.1668 \\
12 & 0.2520 & 0.6389 & 0.1610 \\
24 & 0.2538 & 0.6260 & 0.1587 \\
36 & 0.2448 & 0.6212 & 0.1520 \\
48 & 0.2498 & 0.6215 & 0.1550
\end{tabular}

老化防止劑は一般にゴムを軟化する性質のあることは既に認め られてみるが其可塑性に就ては研究が見當らない。著者等の上表

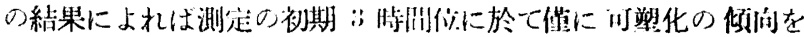


現したが其後は漸減的で殆ど 可塑性なしと云つてよい程度であ ろ。

フェニルトーナフチルフミンはナルドール莱より稍々㜞化性が强 く 3 時間にして同樣最高を示し以下滜隇寸る。

メルカプトペンゾチアゾールとヂフェニルグアニデンとは加硫 促進劑として可成り相違した性質があるが實際上其併用の機會が

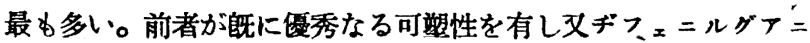

第 3 表 メルカプトベンゾチナゾールを ヂフェニルグアニデンの併用

\begin{tabular}{cccc} 
粶過時間(時) & 軟化度 & 保持度 & 可塑度 \\
\hline 0 & 0.2258 & 0.6208 & 0.1418 \\
1 & 0.2342 & 0.6287 & 0.1445 \\
3 & 0.2392 & 0.6286 & 0.1451 \\
5 & 0.2464 & 0.6299 & 0.1550 \\
7 & 0.2270 & 0.6283 & 0.1436 \\
12 & 0.2470 & 0.6300 & 0.1558 \\
24 & 0.2361 & 0.6252 & 0.1476 \\
36 & 0.2470 & 0.6215 & 0.1438 \\
48 & 0.2232 & 0.6198 & 0.1383
\end{tabular}

笠 4 表 メルカプトベンゾチアゾールと テトラメチルヂサルファイドの併用

\begin{tabular}{cccc} 
·程過時間(時) & 軟化度 & 保持度 & 可塑度 \\
\hline 0 & 0.2646 & 0.6858 & 0.1815 \\
1 & 0.2966 & 0.7151 & 0.2128 \\
3 & 0.3035 & 0.7179 & 0.2172 \\
5 & 0.2972 & 0.7012 & 0.2082 \\
7 & 0.2950 & 0.7005 & 0.2080 \\
12 & 0.2909 & 0.6984 & 0.2030 \\
24 & 0.2904 & 0.6922 & 0.2010 \\
36 & 0.2879 & 0.6839 & 0.1977 \\
48 & 0.2814 & 0.6810 & 0.1915
\end{tabular}

第 5 表 メルカプトベンジチアジールを ブチルアルデヒドアニリンの侀用

\begin{tabular}{cccc} 
稳過時間(時) & 軟化度 & 保持度 & 可塑度 \\
\hline 0 & 0.2503 & 0.6612 & 0.1655 \\
1 & 0.2714 & 0.6741 & 0.1830 \\
3 & 0.2760 & 0.6777 & 0.1816 \\
5 & 0.2700 & 0.6720 & 0.1815 \\
7 & 0.2724 & 0.6719 & 0.1827 \\
12 & 0.2669 & 0.6684 & 0.1774 \\
24 & 0.2655 & 0.6671 & 0.1772 \\
36 & 0.2735 & 0.6705 & 0.1830 \\
48 & 0.2730 & 0.6700 & 0.1820
\end{tabular}

第 6 表 メルカプトベンジチアジールと ヘキサメチレンテトラミンの仵用

\begin{tabular}{cccc} 
經過時間(時) & 般化度 & 保特度 & 可塑度 \\
\hline 0 & 0.2455 & 0.6366 & 0.1562 \\
1 & 0.2435 & 0.6260 & 0.1523 \\
8 & 0.2337 & 0.6151 & 0.1436 \\
5 & 0.2279 & 0.6133 & 0.1397 \\
7 & 0.2241 & 0.6116 & 0.1370 \\
12 & 0.2215 & 0.6092 & 0.1350 \\
24 & 0.2211 & 0.6010 & 0.1330 \\
36 & 0.2198 & 0.5988 & 0.1315 \\
48 & 0.2199 & 0.5981 & 0.1314
\end{tabular}

第 7 表 メルカプトベンゾチアジールと ピペリヂルベンタメチレンヂチオカーバメートの併用

\begin{tabular}{cccc} 
橙過時間(時) & 软化度 & 保持度 & 可塑度 \\
\hline 0 & 0.2678 & 0.6430 & 0.1702 \\
1 & 0.2488 & 0.6278 & 0.1560 \\
3 & 0.2501 & 0.6303 & 0.1576 \\
5 & 0.2422 & 0.6268 & 0.1513 \\
7 & 0.2503 & 0.6279 & 0.1580 \\
12 & 0.2488 & 0.6177 & 0.1535 \\
24 & 0.2477 & 0.6168 & 0.1527 \\
36 & 0.2327 & 0.6076 & 0.1410 \\
48 & 0.2310 & 0.6051 & 0.1399
\end{tabular}
ヂンが僅に可塑性あるに拘らず併用の場合には好しき曲線を現す が其效果は前者の牛ばに過ぎない。ブチルアルデヒドアニリン, へキサメチレンテトラミンは夫自身僅に可塑性を示したことは前 報に述べたるところなるが併用の場合には全く可䩗性を認めなか つた。

第 8 表 メ几カプトヘンン゙チアデールと アルドール

\begin{tabular}{cccc} 
經過時間(時) & 軟化度 & 保持度 & 可塑度 \\
\hline 0 & 0.2467 & 0.6420 & 0.1584 \\
1 & 0.2506 & 0.6508 & 0.1630 \\
3 & 0.2615 & 0.6562 & 0.1716 \\
5 & 0.2546 & 0.6512 & 0.1658 \\
7 & 0.2490 & 0.6500 & 0.1621 \\
12 & 0.2458 & 0.6425 & 0.1579 \\
24 & 0.2411 & 0.6376 & 0.1536 \\
36 & 0.2386 & 06298 & 0.1500 \\
48 & 0.2315 & 0.6275 & 0.1453
\end{tabular}

第 9 表 メルカプトベンジチアゾールを $>_{x}=ル \boldsymbol{\beta}$-ナフチルアミンの併用

\begin{tabular}{cccc} 
經過時間(時) & 僌化度 & 保持度 & 可塑度 \\
\hline-0 & 0.2426 & 0.6493 & 0.1575 \\
1 & 0.2588 & 0.6511 & -0.1682 \\
3 & 0.2568 & 0.6491 & 0.1667 \\
5 & 0.2599 & 0.6499 & 0.1685 \\
7 & 0.2576 & 0.6425 & 0.1655 \\
12 & 0.2558 & 0.6401 & 0.1636 \\
24 & 0.2452 & 0.6315 & 0.1548 \\
36 & 0.2410 & 0.6298 & 0.1516 \\
48 & 0.2350 & 0.6115 & 0.1440
\end{tabular}

メルカプトベンゾチアゾールとアルドール $\propto$-ナフチルアミン 及びフェニル $\beta$-ナフチルアミンの侀用の場合は兩者共メルカブ トベンジチアゾールの可塑性を消隇せしめた。其曲線を見ると老 化防止劑單獨の場合と殆ど異らない。

\section{3. 結果の考察}

アルドール ムーナフチルアミンは樹脂狀物質で生ゴムに配合し た場合軟化齌として作用すべきことは前に述べたところである が, 實驗に現れた結果も軟化劑としての程度で極めて微弱なる可 望性を現した。フェニル $\beta$-ナフチルフミンす同樣で殆ど類似の曲 線を示した。メルカプトベンゾチアゾールとの併用に於ては當然 此化合物が第 2 級アミンを構成することより可塑性は完全に消 失すべきに拘らず第 1 圖に示した曲标の如く作用前と同棁な結 
果を與へたる點より見て其曲線の現れは㜞化性に基因すると說明 枉來る。

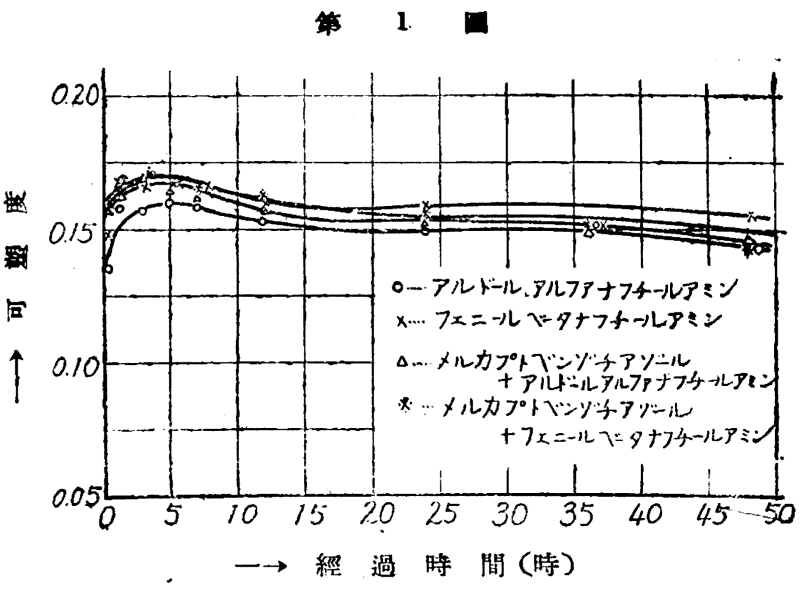

メルカプトベンデチアゾールと他の促進劑との作用は加硫促進 劑としての場合には種々併用により特性發揮の改良が行はれたが 可塑性に就ては概してメルカプタンの可塑能を消隇せしめるか或 は著しく娍退を來し，場合によつては全く逆作用を星することが 殌驗された。

郎ちメルカプトペンゾチアゾールとデフェ ニルグアニヂン， 第 $\quad 2$ 圆

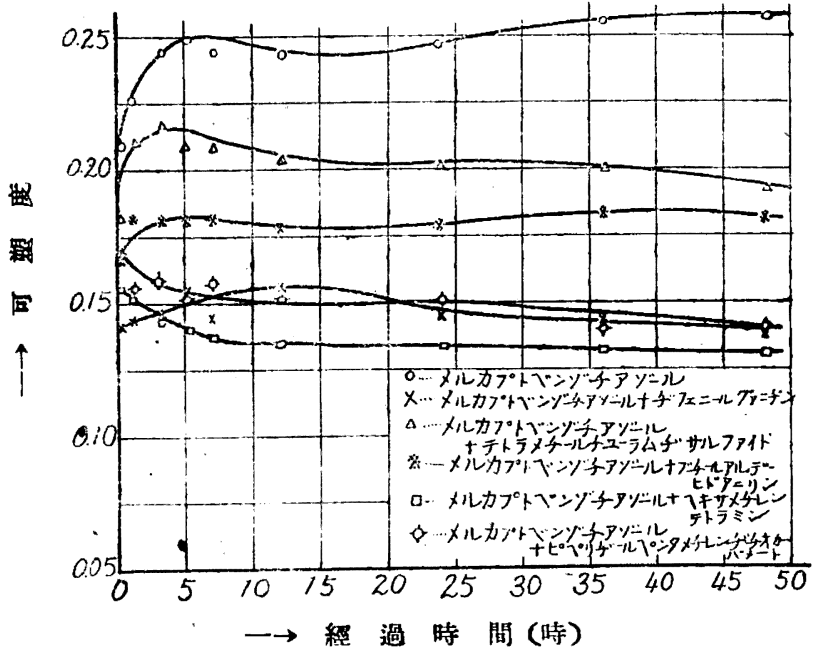

キサメチレンテトラミン，ピペリヂルペンタメチレンヂチオカー 天メートの如きは第 2 圖に見らる」如く類似の曲線を現し反可塑 性の性格を示した。而して前二者は單獨にては幾分なりとも可塑 性を認められたに拘らず，併用に於てはメルカブタンの可塑性を 消失したのみならず夫自身の力をす失ひたるは興味ある事實であ る。

ブチルアルデヒドァニリンの併用に於てはメルカプタンの可塑 性は洞失するす僅に自體の力を保持し，テトラメチルチューラム ヂサルフ イイドの併用に於ては兩者の和の牛ばに等しい可塑性を 示した。此問題は兩者の化學的構造より見て了解に苦しむところ なるが他に化學構造上の關係が伏在する如くであり，他日の研究 に侯つて解明したいと思ふ。

著者等は既に本研究の第 4 及び 7 報に於て化合物中： ミ , イミノ基の如き残基が存在する場合にはメルカプタンの可塑性は 大いに抑制を受けることを指摘したが其場合には㛙れる單獨化合 物の分子內構造に關係して說明した。促進劑の作用貝驗を通じて 觀察するに促進劑並に老化防止劑共に殆どアミノ基又はイミノ基 を保有せざる化合物は少い。故にメルカプタンの可塑性の消失せ らるっことは首肯出來るのである。而して前に報告したる残基の 扣制作用に就て本研究に於ても隻書寸る結果となつた。

要するに加硫促進劑中には多少の可塑性を有するものあること を知つたっ幸に最す優秀なる可塑性を持つメルカプトペンゾチす ゾールは促進劑中重要にして廣範圍に使用せられ，之を促進劑と して以外に可塑能を活用して素徚時間の短縮に應用し得るとすれ ば大なる便益がある。前述の如く促進劑は單獨にて使用する場合 少く 2 種以上數種を例用寸る場合が多く，更に老化防止劑等の併 用があり極めて複雜である。特定の探用すへきき配合䒚品は配合の 順序に注意し促淮劑の有する可塑性は充分活用すべきで䁇ろ單獨 に使用して充分なる可塑效果を發揮せしむべきである。

\section{4. 䌆括}

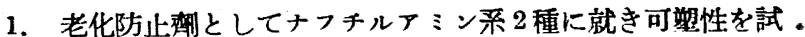
鍳したが軟化性程度であつた。

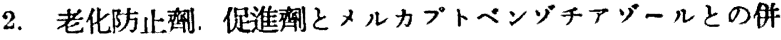
用は概してメルカプタンの可塑性を減殺する。

3. メルカプトペンゾチアデールとテトラメチルチューラムヂ サルファイドの件用は兩者の可塑性の和の牛ばに娍少する。 本研究行就き熱心に貫驗された森山亮君の勞を多とする。 